\title{
Rational application of fructose-1,6-diphosphate: From the perspective of pharmacokinetics
}

\author{
TING-TING LI ${ }^{1,2}$ \\ JIAN-ZHONG XIE ${ }^{2}$ \\ LING WANG ${ }^{1}$ \\ YANG-YANG GAO \\ XUE-HUA JIANG ${ }^{1 *}$ \\ ${ }^{1}$ Key Laboratory of Drug Targeting \\ and Drug Delivery System of Ministry \\ of Education, West China School \\ of Pharmacy, Sichuan University \\ Chengdu, China \\ 2 Pharmacy Department of People's \\ Hospital of Xishuangbanna Dai \\ Autonomous Prefecture, Jinghong \\ China
}

Accepted December 22, 2014

\begin{abstract}
Fructose-1,6-diphosphate (FDP), a glycolytic metabolite, has been reported to protect susceptible organs during hypoxia or ischemia. However, there is paucity of human data on its pharmacokinetics after being exogenously administered. In the current study, the preliminary pharmacokinetics of FDP given orally to humans was investigated, and no typical peak was observed in the serum drug-time curve. Then, the pharmacokinetic studies were performed following multiple doses of FDP in rats, and the Caco-2 monolayer model was used to study the absorption of FDP in vitro. The results suggested that plasma FDP concentration was significantly increased after oral multiple doses of $180 \mathrm{mg} \mathrm{kg}^{-1}$ but not $90 \mathrm{mg} \mathrm{kg}^{-1}$ of FDP, and FDP was partly depleted during the absorption, which was supposed to be consumed by the intestinal epithelium cells. Thus, we conclude that a high dose of FDP should be orally administered in order to get an effective plasma level.
\end{abstract}

Keywords: fructose-1,6-diphosphate, ischemia, hypoxia, pharmacokinetics

Fructose-1,6-diphosphate (FDP) is an endogenous intermediate metabolite of glucose. Most of glucose and fructose is converted to FDP when entering a cell. It has been increasingly recognized that FDP can protect ischemic or hypoxic tissue after acute ischemia, although the mechanisms have not been fully clarified yet.

Previous studies suggested that exogenous FDP could augment the anaerobic carbohydrate utilization and improve the cellular energy metabolism in ischemic and hypoperfused tissues. Hypoxia forces ischemic tissue to anaerobic glycolysis for energy, which yields two molecules of ATP per glucose in contrast to 36 molecules of ATP generated during oxidative phosphorylation (1). Addition of exogenous FDP can produce two more molecules of ATP in an uncompensated anaerobic environment and hence facilitate the recovery of ischemia tissue. FDP breaks down into glyceraldehyde-3-phosphate and dihydroxyacetone phosphate, which will further break down into two molecules of pyruvate and finally produce two molecules of ATP (Fig. 1).

\footnotetext{
* Correspondence; e-mail: jxh1013@vip.163.com
} 


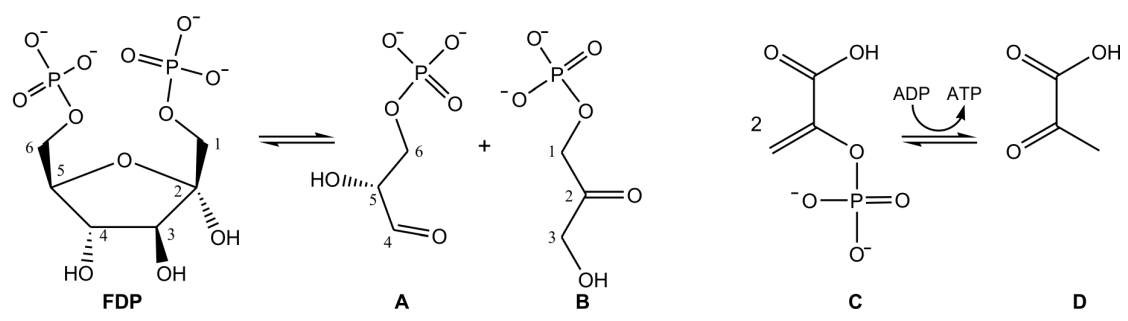

Fig. 1. The role of fructose-1,6-diphosphate (FDP) in energy metabolism. A - glyceraldehyde-3-phosphate, $\mathrm{B}$ - dihydroxyacetone phosphate, $\mathrm{C}$ - phosphoenolpyruvate, $\mathrm{D}$ - pyruvate.

Other mechanisms include inhibition of the generation of oxygen free radicals by neutrophils, stabilization of cell membranes, and maintainance of the correct xanthine dehydrogenase/oxidase ratio by preventing the depletion of phosphorylated compounds in ischemic tissues $(2,3)$.

In myocardial infarction patients, FDP can improve the hemodynamic parameters, attenuate ECG proven ischemic injury and arrhythmia, prevent ATP and creatine phosphate depletion from ischemic myocardium, reduce infarct size, and increase survival rate (4). Exogenously administered FDP has also been proven beneficial for a variety of other ischemic organs, such as liver, kidney, bowel and even brain as a consequence of its ability to penetrate to the blood brain barrier (5-7). In China, FDP has been approved and marketed as a commercial drug.

The pharmacokinetic study of FDP is demanding due to endogenous interferences. A very high dose is needed to achieve a substantial increase of FDP plasma concentration and generate a comprehensive plasma concentration-time course. Doses used in the animal study varied from 350 to $700 \mathrm{mg} \mathrm{kg}^{-1}$ when given by gavage or intraperitoneally $(8,9)$.

According to $\mathrm{Xu}$ and Stringer (10), a complete time course of the levels in blood and brain was observed after intraperitoneal administration of a single $500 \mathrm{mg} \mathrm{kg}^{-1}$ dose of FDP to adult male Sprague-Dawley rats. The recommended dose for patients is $1 \mathrm{~g}$, tid, i.e., 42.8 $\mathrm{mg} \mathrm{kg}^{-1}$ per day. In this study, we first investigated whether the currently recommended total daily dose of FDP $\left(3 \mathrm{~g}\right.$, $\left.42.8 \mathrm{mg} \mathrm{kg}^{-1}\right)$ was adequate to increase the plasma level of FDP in human volunteers. Then, a study was conducted to investigate the pharmacokinetic profile of FDP in rats.

\section{EXPERIMENTAL}

\section{Materials}

Fructose diphosphate sodium tablets ( $1 \mathrm{~g}$ of FDP per tablet) and the corresponding placebo tablets were manufactured by Ling Kang Pharmaceutical Co., Ltd. (China). The FDP standard $\left(\mathrm{C}_{6} \mathrm{H}_{11} \mathrm{Na}_{3} \mathrm{O}_{12} \mathrm{P}_{2} \cdot 8 \mathrm{H}_{2} \mathrm{O}, M_{\mathrm{r}} 550.17\right.$, purity $\left.73.4 \%\right)$ was purchased from the National Institute for the Control of Pharmaceutical and Biological Products (China). Blank plasma was supplied by the West China Hospital, Sichuan University (Chengdu, Sichuan, China) and was covered by institutional approval. The special solid complex enzyme reagent, a 
mixture of aldolase (ALD), triosephosphate isomerase (TIM) and glycerol-3-phosphate dehydrogenase (GDH) in a certain proportion, was purchased from Chung Yi Long Run Co., Ltd. (China), and nicotinamide adenine dinucleotide (NADH) from Sinopharm Chemical Reagent Co., Ltd. (China). The deionized water used in this study was purified using a Millipore AFS-10 water purification system (Millipore, USA). All other chemicals were of analytical grade and were purchased from local chemical suppliers.

Caco-2 cells were supplied by the Type Culture Collection of the Chinese Academy of Sciences (Shanghai, China). Dulbecco's modified eagle's medium (DMEM) was purchased from Gibco Laboratories (Life Technologies Inc., USA), HyClone ${ }^{\mathrm{TM}}$ fetal calf serum from Thermo Fisher Scientific (USA), and trypsin-EDTA solution (0.25\%) from Amresco (USA). Hank's balanced salts solution (HBSS) was purchased from Solarbio (Beijing Solarbio Science \&Technology Co., Ltd., China). Polycarbonate filter membranes (Transwell inserts) were obtained from Corning Costar Corp. (Corning, USA).

\section{Assay development}

Analytical methods and principles. - FDP concentration was determined by monitoring the absorbance of NADH reduced by a special solid complex enzyme (ALD, TIM and GDH) reagent. Aldolase (ALD) cleaves FDP into dihydroxyacetone phosphate (DAP) and $D$-glyceraldehyde 3-phosphate (GAP). Then DAP and GAP are interconverted by the enzyme triosephosphate isomerase (TIM). In the presence of the above reaction products, glycerol-3-phosphate dehydrogenase (GDH) catalyzes the reduction of DAP by NADH (10).

Briefly, $30 \mathrm{mg}$ of the special solid complex enzyme and $3 \mathrm{mg}$ of NADH were dissolved in $10 \mathrm{~mL}$ of tetraethylammonium buffer (TEA, $0.4 \mathrm{~mol} \mathrm{~L}^{-1}, \mathrm{pH} 7.6$ with $40 \mathrm{mmol} \mathrm{L}^{-1}$ of EDTA) before analysis, which was called »mingle enzyme«. For FDP measurements, $2 \mathrm{~mL}$ of TEA buffer and $1 \mathrm{~mL}$ of the »mingle enzyme « were added into a 4 -mL cuvette, followed by mixing for $5 \mathrm{~min}$ at room temperature. The absorbance was then repeatedly measured each minute for $10 \mathrm{~min}$ at $340 \mathrm{~nm}$. The concentration of FDP in the sample was proportional to the change of absorbance intensity.

FDP standard (54.51 mg) was accurately weighed and dissolved in $10 \mathrm{~mL}$ of deionized water to prepare the stock solution. Working solutions of FDP with concentrations of 12.5, $25,50,100,200,400,500 \mu \mathrm{g} \mathrm{mL}^{-1}$ were prepared by appropriately diluting the stock solution using deionized water (for FDP analysis in plasma) or Hank's Balanced Salt Solution (HBSS) (for FDP analysis in the transport medium). The stock solution and working solutions were stored at $4{ }^{\circ} \mathrm{C}$ and tested to be stable for at least 1 month. Calibration standards for FDP analysis in plasma were prepared by spiking $50 \mu \mathrm{L}$ of working solutions into $500 \mu \mathrm{L}$ of blank plasma (for FDP analysis in plasma) or HBSS (for FDP analysis in the transport medium). Three levels of QC samples were chosen as low, medium and high calibration standard concentrations, i.e., 25,100 and $400 \mu \mathrm{g} \mathrm{mL}^{-1}$. The QC samples were stored at $-20{ }^{\circ} \mathrm{C}$ with the sample to be analyzed. Blank sample and FDP standard samples were run in parallel with every assay. The environmental temperature for detecting FDP was set at $25^{\circ} \mathrm{C}$.

\section{Method validation}

Method validation was done by evaluating linearity, intra-day and inter-day precision as well as accuracy and recovery. The QC samples were prepared by spiking the three 
levels of QC working solutions $\left(25,100\right.$ and $\left.400 \mu \mathrm{g} \mathrm{mL}^{-1}\right)$ into blank plasma. Accuracy and precision of the method were assessed by determining QC samples using five replicate preparations on 3 separate days. Extraction recoveries at low, medium and high concentrations were evaluated by comparing the change of absorbance intensity obtained from the QC samples with that from the samples prepared by spiking working solutions into deionized water.

\section{Pharmacokinetic studies}

Study participants. - Preliminary pharmacokinetic studies in humans were performed in two healthy male Chinese volunteers (21 and 22 years old) by administering the doses of $3 \mathrm{~g}$ FDP $\left(\sim 43 \mathrm{mg} \mathrm{kg}^{-1}\right)$. Two healthy male Chinese volunteers (body mass 70.3 and 69.5 $\mathrm{kg}$ ) were selected after clinical assessment of their health status to ensure that they had no history or current evidence of any gastrointestinal, hepatic, renal, or hematologic abnormality, acute infection, chronic disease, or allergy to any drugs. Both of them were nondrinkers and nonsmokers, and did not use drugs for 2 weeks before the study. The protocol was approved by the Ethics Committee of the Xijing Hospital, Fourth Military Medical University of Chinese People's Liberation Army. Both provided written informed consent.

Food intake may modify the pharmacokinetics of a drug by altering the bioavailability of the drug during absorption (11). Caffeinated and alcoholic beverages may also affect the metabolism of certain drugs (12). In this study, volunteers were fasted for at least 12 hours. Food and beverage were prohibited for 4 hours post dosing. Consumption of beverages containing caffeine or alcohol was not allowed during the study.

Study design and drug administration. - The study was conducted with a single blind and parallel design. The first day, two volunteers received a single 3-g oral dose of placebo and 4-mL blood sample was drawn into a heparinized tube before and at $0.25,0.5,0.75,1,1.25$, $1.5,2,2.5,3,4,5,6$ and $8 \mathrm{~h}$ post dose to analyze the baseline levels of FDP in plasma. The next day, they received the same oral dose of FDP and the corresponding blood samples were collected as aforementioned. Blood samples were centrifuged at $4000 \mathrm{rpm}$ for $5 \mathrm{~min}$. The plasma sample was separated and stored at $-20^{\circ} \mathrm{C}$ until analysis.

Sample preparation. - Fifty $\mu \mathrm{L}$ of deionized water was added to $0.5 \mathrm{~mL}$ of plasma sample and mixed. Then, $50 \mu \mathrm{L}$ perchloric acid $(30 \%, \mathrm{~m} / \mathrm{m})$ was added and mixed for $5 \mathrm{~min}$. After centrifugation at $12000 \mathrm{rpm}$ for $5 \mathrm{~min}$ at $4{ }^{\circ} \mathrm{C}$, the supernatant was collected in another tube and $20 \mu \mathrm{L}$ of sodium carbonate solution $\left(2.5 \mathrm{~mol} \mathrm{~L}^{-1}\right)$ was added in order to adjust the $\mathrm{pH}$ to 3.5. Then, the samples underwent another mixing and centrifugation at $12000 \mathrm{rpm}$ for 5 min at $4{ }^{\circ} \mathrm{C}$. The supernatant was collected and used for determination of FDP levels as described above.

\section{Pharmacokinetic studies of FDP}

The pharmacokinetic study of FDP following oral administration was carried out using adult male Sprague-Dawley rats (180-230 g) obtained from the Laboratory Animal Center of West China University of Medical Science (Sichuan, China). All the animals were housed individually with free access to food and water under standard conditions (controlled temperature and humidity with 12-h light:dark cycles). Animal experiments in this 
study were conducted in accordance with the Guidelines for the Care and Use of Laboratory Animals and were approved by the Institutional Animal Care and Use Committee of Sichuan University.

Ten rats were randomly divided into low dose $\left(90 \mathrm{mg} \mathrm{kg}^{-1}\right)$ or high dose $\left(180 \mathrm{mg} \mathrm{kg}^{-1}\right)$ groups. FDP was dissolved in phosphate buffered saline $(\mathrm{pH}=7)$ to a concentration of 10 $\mathrm{mg} \mathrm{mL}^{-1}$. The rats received FDP three times a day for 7 consecutive days. Before dosing, $0.4 \mathrm{~mL}$ of blood was drawn after $12 \mathrm{~h}$ fasting as a control sample to measure the baseline. On the morning of the eighth day, $0.4-\mathrm{mL}$ blood samples were drawn from the tail vein before and at 10, 20, 30 and $45 \mathrm{~min}$ and 1.0, 1.5, 2.0, 3.0, 4.0, 6.0, 8.0, $12.0 \mathrm{~h}$ after the dose. Samples were centrifuged at $4000 \mathrm{rpm}$ for 5 minutes and plasma was separated and stored at $-20^{\circ} \mathrm{C}$ until analysis.

\section{Study of biliary excretion of FDP in rats}

Ten adult male rats were randomly divided into two groups (test and control). The rats received either FDP (180 $\mathrm{mg} \mathrm{kg}^{-1}$, three times a day) or equal amount of phosphate buffered saline by gavage for 7 consecutive days. On the eighth day, after the last dose, bile samples were taken after 2, 4, 6, 8 and $12 \mathrm{~h}$ from the bile duct cannulation. All bile samples were stored at $-20{ }^{\circ} \mathrm{C}$ for later analyses.

\section{Absorption of FDP on monolayers of human intestinal epithelial (Caco-2) cells}

Cell culture. - Caco-2 cells were cultured in high glucose Dulbecco's modified Eagle's medium (DMEM) supplemented with $10 \%$ fetal bovine serum. Cells were cultured in a humidified atmosphere of $5 \% \mathrm{CO}_{2}$ at $37^{\circ} \mathrm{C}$. After reaching $80 \%$ confluence, the Caco- 2 cells were harvested using $0.25 \%$ trypsin-EDTA. For transport experiments, the cells were seeded onto polycarbonate filter membranes in 6-well plates at a density of $1.0 \times 10^{5}$ cells $\mathrm{cm}^{-2}$ and grown for 21 days before the experiments. The protocols for cell culture in the polycarbonate filter membranes were similar to those described previously (13).

Cytotoxicity of FDP. - The cytotoxicity of FDP to Caco-2 cells was examined using a sulforhodamine B (SRB) approach. Briefly, Caco-2 cells were seeded onto 96-well plates (0.1 $\mathrm{mL}$ per well, containing 500 cells per well) and incubated for $48 \mathrm{~h}$ at $37^{\circ} \mathrm{C}$. Then, cells were incubated with various concentrations of $\operatorname{FDP}(0,10,40,80,100,120,140,160,200,300,400$ $\mu \mathrm{g} \mathrm{mL} \mathrm{m}^{-1}$ ) for $3 \mathrm{~h}$. Afterwards, the cells were fixed using methanol and cellular proteins were dyed with $0.1 \mathrm{~mL} 0.4 \%(\mathrm{~m} / \mathrm{V})$ SRB in $1 \%$ acetic acid. Cell-bound dye was dissolved with $0.1 \mathrm{~mL} 10 \mathrm{mmol} \mathrm{L}^{-1}$ Tris buffer $(\mathrm{pH}=10.5)$ and the absorbance of each concentration was measured at $492 \mathrm{~nm}$. No FDP treated group was set as control. Cell viability was proportional to the absorbance.

Transport experiments. - The integrity and transportation ability of the Caco- 2 cell monolayer were examined by measuring the transepithelial electrical resistance (TEER) with an epithelial volt-ohm meter and detecting the activity of alkaline phosphates. Only the cell monolayer with a TEER of above $500 \mathrm{ohm} \mathrm{cm}^{-2}$ was used for transport assays. Differentiation of Caco-2 cells was checked on the 3rd and 14th day by determining the activity of alkaline phosphates. 
After washing the Caco-2 cell monolayer twice with HBSS medium $(\mathrm{pH}=7.4)$ prewarmed to $37^{\circ} \mathrm{C}$, transport experiments were conducted by adding the FDP solutions to the apical chamber (AP, $1.5 \mathrm{~mL}$ ) while $2.5 \mathrm{~mL}$ of blank HBSS medium was added to the basolateral (BL) chamber. After 0, 15, 30, 45, 60, 75, 90, 105, 120, 150 and 180 min incubation at $37^{\circ} \mathrm{C}$, a $0.1-\mathrm{mL}$ sample was collected from the BL side to study the drug transport of the apical to basolateral (AP to BL) chamber and meanwhile an equal volume of blank HBSS was replenished to BL. Also, 0.1-mL samples from the AP side were collected at the beginning and at the end of the experiment. Three loading concentrations of 100, 200 and $400 \mu \mathrm{g}$ $\mathrm{mL}^{-1}$ were used in triplicate. All samples were preserved at $-20^{\circ} \mathrm{C}$ until analysis.

FDP released by Caco-2 cells. - Caco-2 cells were cultured in high glucose Dulbecco's modified Eagle's medium (DMEM) for 21 days, followed by replacing it with flesh medium and incubating for another $48 \mathrm{~h}$ (14). The medium at the end of the 48 -h incubation was collected to determine the FDP concentration compared to that in fresh medium. All samples were preserved at $-20^{\circ} \mathrm{C}$ until analysis.

\section{Data analysis}

The cumulative mass $(\mu \mathrm{g})$ of FDP in the basolateral (BL) chamber at time $i$ was calculated using the following formula:

$$
\mathrm{QrBi}=0.1 \times[\gamma \mathrm{r} 1+\gamma \mathrm{r} 2+\ldots+\gamma \mathrm{r}(\mathrm{i}-1)]+2.5 \times \gamma \mathrm{ri}
$$

where QrBi $(\mu \mathrm{g})$ is the cumulative amount of FDP in BL chamber, $\gamma \mathrm{r} 1$ is the FDP level $(\mu \mathrm{g}$ $\mathrm{mL}^{-1}$ ) of the sample in BL chamber from the first time point, $\gamma \mathrm{ri}$ is the level of the sample at time $i$ in BL chamber, and 2.5 refers to the volume of BL chamber $(2.5 \mathrm{~mL})$.

Usually, drugs that are well absorbed in the intestine have permeability coefficients $>1 \times 10^{-6} \mathrm{~cm} \mathrm{~s}^{-1}$, and those which are hardly absorbed have permeability coefficients $\leq 1 \times 10^{-7} \mathrm{~cm} \mathrm{~s}^{-1}$. The apparent permeability coefficient $\left(P_{\text {app }}\right)$, the coefficient that reflects the absorption of a drug, was calculated based on the following equation:

$$
P_{\text {app }}=\frac{d Q}{d t} \times \frac{1}{A \gamma_{0}}
$$

where $\mathrm{d} Q / \mathrm{d} t\left(\mu \mathrm{g} \mathrm{s}^{-1}\right)$ is the cumulative transport rate of the compound on the receiving side, A is the surface area of the cell monolayer $\left(\mathrm{cm}^{2}\right)$, and $\gamma_{0}$ is the initial concentration in the donor compartment $\left(\mu \mathrm{g} \mathrm{mL}^{-1}\right)$.

The recovery and absorption ratio of the transport experiment was calculated as:

$$
\begin{gathered}
\operatorname{Recovery}(\%)=\frac{\gamma_{\mathrm{Af}} \times V_{\mathrm{A}}-\gamma_{\mathrm{Bf}} \times V_{\mathrm{B}}}{\gamma_{\mathrm{A} 0} \times V_{\mathrm{A}}} \\
\text { Absorption ratio }(\%)=\frac{\gamma_{\mathrm{Bf}} \times V_{\mathrm{B}}}{\gamma_{\mathrm{A} 0} \times V_{\mathrm{A}}}
\end{gathered}
$$


where $\gamma_{\mathrm{Af}}, \gamma_{\mathrm{Bf}}$ and $\gamma_{\mathrm{A} 0}$ refer to the final concentration of FDP in the AP chamber, BL chamber, and initial concentration of FDP in AP chamber respectively, and $V_{A}$ and $V_{B}$ are the volume of $\mathrm{AP}$ and $\mathrm{BL}$ chambers.

\section{Statistical analysis}

Pharmacokinetic parameters were determined using the DAS version 3.1.6. $\gamma_{\max }$ and $t_{\max }$ were determined using visual inspection of the FDP plasma concentration-time flot. All results were expressed as mean \pm SEM. The time course for FDP in plasma was analyzed with a one-way ANOVA comparing it to control levels as a function of time. Other comparisons were done using Student's test. A $p<0.05$ was considered to indicate a statistically significant difference.

\section{RESULTS AND DISCUSSION}

The intra-day precision of the assay was $8.8,5.8$ and $5.6 \%$ and the inter-day precision are 9.7, 7.3 and $6.5 \%$ for the low, medium and high concentration of FDP, respecting. The accuracies were 93.2, 96.2 and $91.8 \%$ for the low, medium and high concentration of FDP, respectively. A good linear relationship was obtained in the range of $12.5-500 \mu \mathrm{gL} \mathrm{m}^{-1}$ in plasma and HBSS. The lower limit of quantification $(L L O Q)$ was $12.5 \mu \mathrm{g} \mathrm{mL}^{-1}$. The mean extraction recovery was $91.8 \pm 7.81,96.2 \pm 7.8$ and $93.2 \pm 2.5 \%$ for the low, medium and high concentration of FDP, respectively.

\section{Pharmacokinetics of FDP in human plasma}

The FDP plasma concentration-time courses of the volunteers following oral administration of $3 \mathrm{~g}$ FDP or placebo are shown in Figs. $2 \mathrm{a}$ and $2 \mathrm{~b}$. Each point represents the concentration of FDP at the corresponding time. The concentration of FDP at baseline level varied from 58.61 to $110.64 \mu \mathrm{g} \mathrm{mL}^{-1}$ and 34.14 to $116.26 \mu \mathrm{g} \mathrm{mL}^{-1}$ for subjects $\mathrm{A}$ and $\mathrm{B}$, respectively, which indicated physiological fluctuations. The peak concentration $\left(\gamma_{\max }\right)$ and the time to achieve it $\left(t_{\max }\right)$ in volunteer A were $113.34 \mu \mathrm{g} \mathrm{mL}-1$ and $3 \mathrm{~h}$, and that for volunteer $B$ were $119.83 \mu \mathrm{g} \mathrm{mL}^{-1}$ and $1.5 \mathrm{~h}$.

No significant difference in FDP plasma concentration was observed at 8 hours post dose of FDP tablets and placebo $\left(89.10 \pm 3.15\right.$ vs. $82.58 \pm 3.72 \mu \mathrm{g} \mathrm{mL}^{-1}$ for subject A, while $83.47 \pm 4.39$ vs. $84.42 \pm 5.39 \mu \mathrm{g} \mathrm{mL}^{-1}$ for subject $\mathrm{B}$ ). The results demonstrated that FDP failed to rise in plasma of humans at a dose of $3 \mathrm{~g}$ compared to an equivalent dose of placebo, indicating that the currently recommended dose of FDP from tablets may be inadequate to achieve clinically effective concentrations.

\section{Plasma pharmacokinetics and biliary excretion of FDP in rats}

The FDP plasma concentration in rats following administration of FDP at a dose of 90 $\mathrm{mg} \mathrm{kg}^{-1}$ (every 8 hours for seven consecutive days) was substantially increased compared to the placebo group, although the increase did not reach a statistically significant level (Fig. 2c). $\gamma_{\max }$ and $t_{\max }$ were $118.58 \mu \mathrm{g} \mathrm{mL}^{-1}$ and $45 \mathrm{~min}$, respectively. Average FDP plasma 

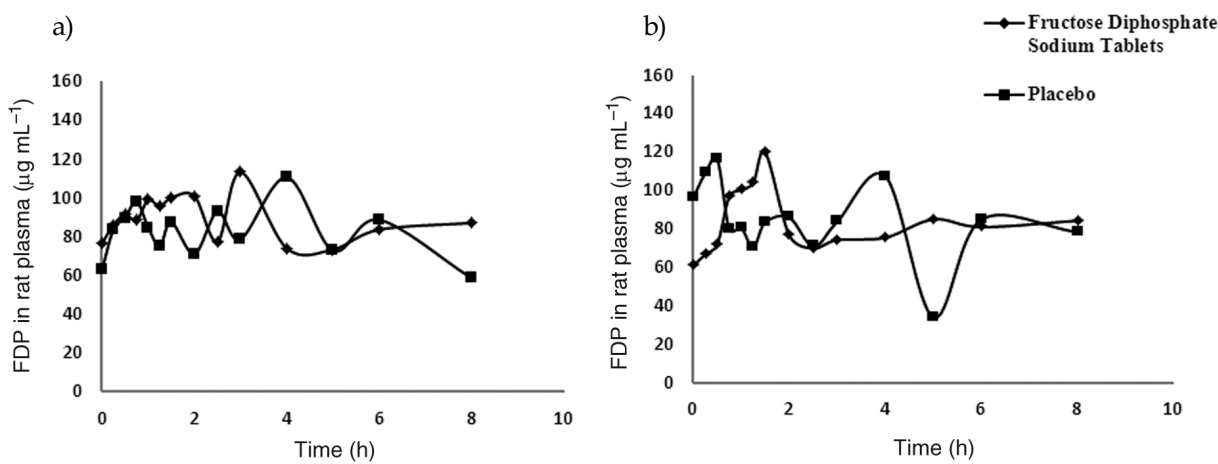

c)

d)
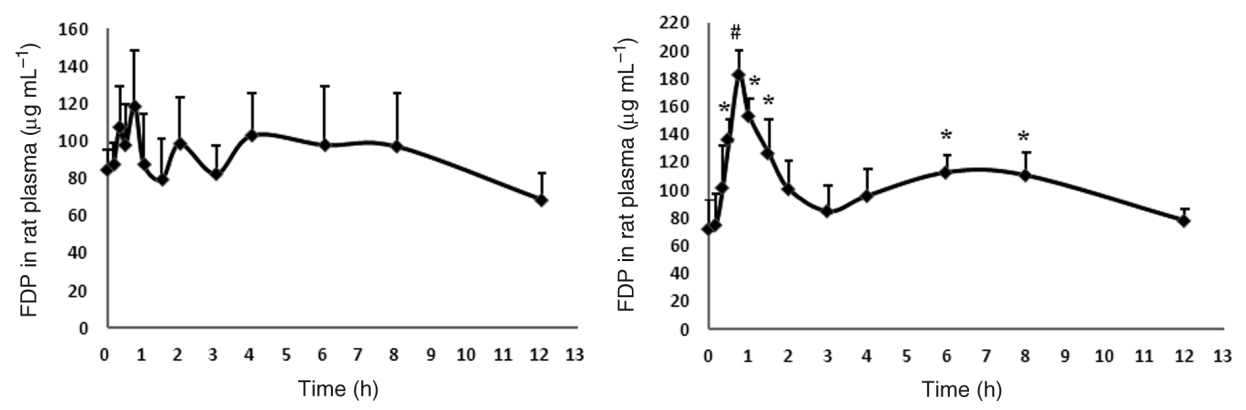

Fig. 2. Level of FDP in plasma of: a) volunteer $A$ and $b$ ) volunteer $B$ after administration of $3 g$ of FDP and placebo. Kinetics of FDP after gavage administration of c) $90 \mathrm{mg} \mathrm{kg}^{-1}$ and d) $180 \mathrm{mg} \mathrm{kg}^{-1}$ of FDP for consecutive seven days in rats. Each point indicates average and standard deviation, $n=5$. Significant difference compared to the control value: ${ }^{*} p<0.05,{ }^{*} p<0.01$.

concentration within $12 \mathrm{~h}$ following oral administration of FDP was $93.61 \mu \mathrm{g} \mathrm{mL}^{-1}$, while the average value in the control group was $84.09 \mu \mathrm{g} \mathrm{mL}^{-1}$.

The FDP plasma concentration in rats following oral administration of $180 \mathrm{mg} \mathrm{kg}^{-1}$ FDP (every 8 hours for seven consecutive days) was increased significantly, especially during the first $0.5-1.5 \mathrm{~h}$ post dose (Fig. $2 \mathrm{~d}$ ). The $\gamma_{\max }$ and $t_{\max }$ were $182.85 \mu \mathrm{g} \mathrm{mL}^{-1}$ and $45 \mathrm{~min}$, respectively. $A U C(0-t), A U C(0-\infty)$ and $t_{1 / 2}$ were $1086.7 \mu \mathrm{g} \mathrm{h}^{-1}, 1975.0 \mu \mathrm{g} \mathrm{L} \mathrm{h}{ }^{-1}$ and $8.14 \mathrm{~h}$, respectively. The mean FDP concentration within $12 \mathrm{~h}$ post dose was $113.28 \mu \mathrm{g} \mathrm{mL}{ }^{-1}$, while average for the control group was $71.98 \mu \mathrm{g} \mathrm{mL}^{-1}$. However, in $\mathrm{Xu}$ and Stringer's study (10), the peak plasma concentration was only about $35 \mu \mathrm{g} \mathrm{mL} \mathrm{L}^{-1}$ after a single dose of $500 \mathrm{mg} \mathrm{kg}^{-1}$ FDP by intraperitoneal injection in rats, which was much lower than that in the present study. The multiple-dose in this study may significantly increase the concentration of FDP compared to the single-dose due to drug accumulation in plasma.

In addition, a bimodal phenomenon on the concentration-time curve was observed. The second concentration peak of $115 \mu \mathrm{g} \mathrm{mL}-1$ was observed at $7 \mathrm{~h}$ post dose (Fig. $2 \mathrm{~d}$ ), which is consistent with Xu and Stringer's study (10). The results indicated that enterohepatic circulation may exist. 
a)

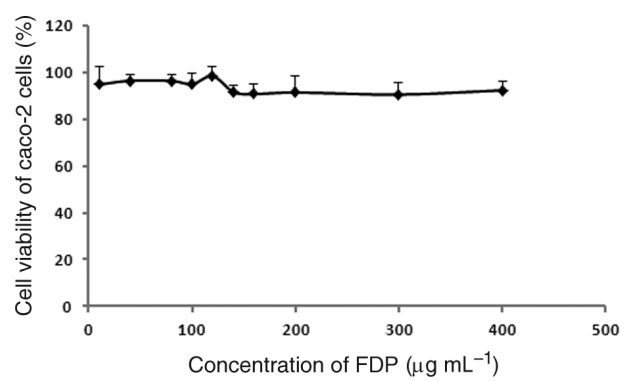

c)

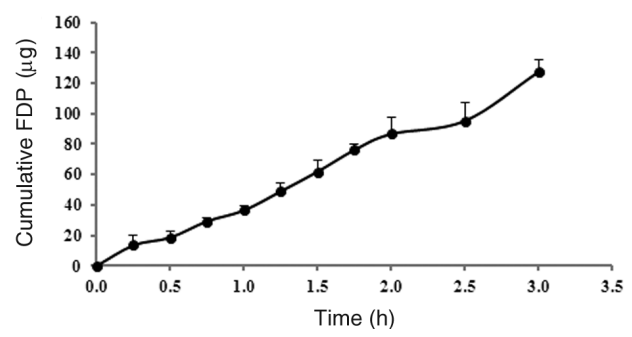

b)

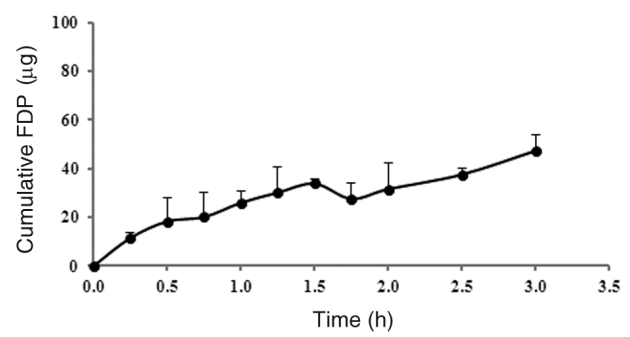

d)

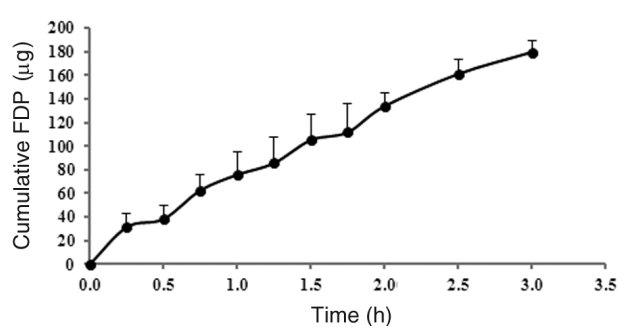

Fig. 3. a) Caco-2 cell viability (\%) at different concentrations of FDP (10, 40, 80, 100, 120, 140, 160, 200, 300 , and $400 \mu \mathrm{g} \mathrm{mL}^{-1}$ ) (mean $\pm \mathrm{SD}, n=5$ for $10 \mu \mathrm{g} \mathrm{mL}^{-1}, n=6$ for others). Time course of FDP transport in Caco-2 cell monolayers at the concentration of: b) $100 \mu \mathrm{g} \mathrm{mL}^{-1}$, c) $200 \mu \mathrm{g} \mathrm{mL}^{-1}$, d) $400 \mu \mathrm{g} \mathrm{mL}{ }^{-1}$ (mean $\pm \mathrm{SD}, n=3)$.

Table I. Permeability of FDP through Caco-2 cells

\begin{tabular}{ccccccc}
\hline $\begin{array}{c}\gamma_{0} \\
\left(\mu \mathrm{g} \mathrm{mL}^{-1}\right)\end{array}$ & $\begin{array}{c}\gamma_{\mathrm{B}} \\
\left(\mu \mathrm{g} \mathrm{mL} \mathrm{mL}^{-1}\right)\end{array}$ & $\begin{array}{c}\gamma_{\mathrm{A}} \\
\left(\mu \mathrm{g} \mathrm{mL}^{-1}\right)\end{array}$ & $\begin{array}{c}\text { QrB3h } \\
(\mu \mathrm{g})\end{array}$ & $\begin{array}{c}\text { Absorption } \\
\text { ratio }(\%)\end{array}$ & $\begin{array}{c}\text { Recovery } \\
(\%)\end{array}$ & $\begin{array}{c}\text { Papp } \\
\times 10^{-5}\left(\mathrm{~cm} \mathrm{~s}^{-1}\right)\end{array}$ \\
\hline 100 & $14.89 \pm 1.318$ & $26.66 \pm 3.292$ & $31.51 \pm 10.78$ & $21.01 \pm 7.19$ & $63.27 \pm 7.214$ & $2.397 \pm 0.5928$ \\
200 & $44.18 \pm 3.491$ & $55.60 \pm 6.700$ & $127.31 \pm 7.83$ & $42.44 \pm 2.61$ & $72.58 \pm 5.048$ & $4.473 \pm 0.7643$ \\
400 & $60.36 \pm 6.262$ & $154.51 \pm 14.259$ & $179.73 \pm 16.01$ & $29.96 \pm 2.67$ & $72.17 \pm 4.318$ & $2.137 \pm 0.2991$ \\
\hline
\end{tabular}

$\gamma_{0}$ - Concentration of FDP in chamber AP at the beginning of transport experiments;

$\gamma_{\mathrm{B}}$ and $\gamma_{\mathrm{A}}$ - Concentration of FDP in chamber BL and chamber AP at the end of transport experiments.

QrB3h - The cumulative amount of FDP in BL chamber after transporting for $3 \mathrm{~h}$.

$\mathrm{P}_{\text {app }}$ - The apparent permeability coefficient.

Mean \pm SD of 3 independent transport experiments.

FDP was not detected in biliary samples from the both test group and control group. Other mechanisms may exist. Following the oral dose of $180 \mathrm{mg} \mathrm{kg}^{-1}$ FDP (every 8 hours for seven days). 


\section{Permeability of FDP through Caco-2 cells}

Cell viabilities of Caco-2 cells in the presence of FDP at concentrations from 10 to 400 $\mu \mathrm{g} \mathrm{mL} \mathrm{m}^{-1}$ were all above $90 \%$, which suggested and released FDP by rather low cytotoxicity of FDP on Caco-2 cells within $3 \mathrm{~h}$ (Fig. 3a).

The amount of FDP in BL chamber increased with time at loading concentrations of 100, 200 and $400 \mu \mathrm{g} \mathrm{mL}^{-1}$ in AP chamber (Figs. 3b, 3c, 3d). At the end of the experiment, the cumulative FDP in BL chamber was $45.53,127.3$, and $179.61 \mu \mathrm{g}$, respectively.

The mean $P_{\text {app }}$ value of FDP at three concentrations is listed in Table I; FDP was found to be high permeable $\left(P_{\text {app }}>1 \times 10^{-6} \mathrm{~cm} \mathrm{~s}^{-1}\right)$. However, the recoveries of FDP were poor $(63$, 68 , and $78 \%$ for 100,200 and $400 \mu \mathrm{g} \mathrm{m}^{-1}$ group respectively). The intracellular FDP concentration was determined at the end of the transport experiment and was found to be very low. The results suggested that FDP could be consumed by Caco-2 cells during the transport experiment. Such a possibility would partially explain low recovery.

Caco-2 cells were cultured for 21 days on polycarbonate filter membranes (surface area $4.52 \mathrm{~cm}^{2}$ ) and were continuously incubated for another $48 \mathrm{~h}$ to investigate the FDP release. The results showed that the level of FDP in the final medium in AP (apical chamber) and BL (basolateral chamber) were $175.35 \pm 2.37$ and $174.51 \pm 5.79 \mu \mathrm{g} \mathrm{mL}^{-1}$, respectively. No FDP was detected in fresh medium, which implied that FDP may be released from Caco-2 cells. The release of endogenous FDP could explain the second peak in the concentration-time curve (Fig. 2d), although further investigation is necessary to verify the hypothesis.

\section{CONCLUSIONS}

The results indicate that the currently recommended dose of FDP may be inadequate to significantly increase the plasma level of FDP and that a higher dose is needed. The consumption of FDP by the intestinal epithelium cells could be a major barrier for FDP absorption. In order to achieve the desired clinical therapeutic effect, a higher dosage may be utilized in clinical settings for mitigating the ischemic injury of organs apart from the intestine itself.

\section{REFERENCE}

1. J. E. Cohen, P. Atluri, M. D. Taylor, T. J. Grand, G. P. Liao, C. M. Panlilio, E. E. Suarez, S. E. Zentko, V. M. Hsu, M. F. Berry, M. J. Smith, T. J. Gardner, H. L. Sweeney and Y. J. Woo, Fructose 1,6-diphosphate administration attenuates post-ischemic ventricular dysfunction, Heart Lung Circ. 15 (2006) 119-123; DOI: 10.1016/j.hlc.2005.12.004.

2. L. Galzigna, V. Rizzoli, M. Bianchi, M. P. Rigobello and R. Scuri, Some effects of fructose-1,6-diphosphate on rat myocardial tissue related to a membrane-stabilizing action, Cell Biochem. Funct. 7 (1989) 91-96; DOI: 10.1002/cbf.290070203.

3. B. Tavazzi, L. Cerroni, D. D. Pierro, G. Lazzarino, M. Nuutinen, J. W. Starnes and B. Giardina, Oxygen radical injury and loss of high-energy compounds in anoxic and reperfused rat heart: prevention by exogenous fructose-1,6-bisphosphate, Free Radic. Res. 10 (1990) 167-176; DOI: 10.3109/10715769009149885. 
4. A. K. Markov, Hemodynamics and metabolic effects of fructose 1,6-diphosphate in ischemia and shock-experimental and clinical observations, Ann. Emerg. Med. 15 (1986) 1470-1477; DOI: 10.1016/ S0196-0644(86)80946-5.

5. X. T. Wu, J. S. Li, X. F. Zhao, N. Li, Y. K. Ma, W. Zhuang, Y. Zhou and G. Yang, Effects of n-3 fatty acid, fructose-1,6-diphosphate and glutamine on mucosal cell proliferation and apoptosis of small bowel graft after transplantation in rats, World J. Gastroenterol. 9 (2003) 1323-1326.

6. T. J. Wheeler, J. M. McCurdy and S. Chien, Permeability of fructose-1,6-bisphosphate in liposomes and cardiacmyocytes, Mol. Cell Biochem. 259(2004)105-114; DOI:10.1023/B:MCBI.0000021356.89867.0d.

7. T. Kaakinen, A. Naukkarinen, H. Tuominen, P. Romsi, M. Nuutinen, F. Biancari and T. Juvonen, Neuronal ultrastructure is preserved by fructose-1,6-bisphosphate after hypothermic circulatory arrest in pigs, J. Thorac. Cardiov. Sur. 130 (2005) 1475-1476; DOI: 10.1016/j.jtcvs.2005.07.037.

8. R. Didlake, K. A. Kirchner, J. Lewin, J. D. Bower and A. K. Markov, Attenuation of ischemic renal injury with fructose 1,6-diphosphate, J. Surg. Res. 47 (1989) 220-226; DOI: 10.1016/00224804(89)90111-X.

9. N. Antunes, C. A. Martinusso, C. M. Takiya, A. J. Silva, J. F. Ornellas, P. R. Elias, M. Leite, Jr. and L. R. Cardoso, Fructose-1,6-diphosphate as a protective agent for experimental ischemic acute renal failure, Kidney Int. 69 (2006) 68-72; DOI: 10.1038/sj.ki.5000013.

10. K. Xu and J. L. Stringer, Pharmacokinetics of fructose-1, 6-diphosphate after intraperitoneal and oral administration to adult rats, Pharmacol. Res. 57 (2008) 234-238; DOI 10.1016/j.phrs.2008.01.008.

11. S. Drabant, I. Klebovich, B. Gachalyi, G. Renczes and C. Farsang, Role of food interaction pharmacokinetic studies in drug development. Food interaction studies of theophylline and nifedipine retard and buspirone tablets, Acta Pharm. Hung. 68 (1998) 294-306.

12. C. S. Won, N. H. Oberlies and M. F. Paine, Mechanisms underlying food-drug interactions: inhibition of intestinal metabolism and transport, Pharmacol. Ther. 136 (2012) 186-201. DOI: 10.1016/j. pharmthera.2012.08.001.

13. L. Yunxia, L. Hongye, X. H. Jiang and C. Peng, Assessment and modulation of phillyrin absorption by P-gp using Caco-2 cells and MDR1-MDCKII cells, Eur. J. Drug Metab. Ph. 36 (2011) 41-47; DOI: 10.1007/s13318-011-0026-0.

14. P. Artursson and J. Karlsson, Correlation between oral drug absorption in humans and apparent drug permeability coefficients in human intestinal epithelial (Caco-2) cells, Biochem. Bioph. Res. Co. 175 (1991) 880-885; DOI: 10.1016/0006-291X(91)91647-U. 